mean that these individuals are presumably less resistant to anticonvulsant therapy than the bulk of those in the trial who represent the "hard core" of uncontrolled drug-resistant epileptics.

Transitory side-effects were seen in 10 patients and sideeffects of sufficient severity to lead to withdrawal of the drug occurred in 28. The nature of these side-effects and their frequency are shown in Table $\mathrm{V}$. No evidence of liver damage or of any blood dyscrasia was found.

TABLE V.-Frequency of the Occurrence of Various Side-effects

\begin{tabular}{|c|c|c|c|c|c|c|c|c|}
\hline \multicolumn{3}{|c|}{$\begin{array}{l}\text { Transitory } \\
\text { Side-effects }\end{array}$} & \multicolumn{6}{|c|}{ Severe and Prolonged Side-effects } \\
\hline $\begin{array}{l}\text { Headache } \\
\text { Paraesthesiae } \\
\text { Dyspnoea } \\
\text { Nausea . B virring of visio } \\
\text { Drowsiness }\end{array}$ & $\begin{array}{l}\because \\
\ddot{ } \\
\ddot{n} \\
\cdots\end{array}$ & $\begin{array}{l}3 \\
3 \\
2 \\
2 \\
2 \\
1\end{array}$ & $\begin{array}{l}\text { Ataxia .. } \\
\text { Drowsiness } \\
\text { Confusion } \\
\text { Headache } \\
\text { Psychotic re } \\
\text { (schizophre } \\
\text { psychosis 2; } \\
\text { depression } \\
\text { Vertigo .. }\end{array}$ & $\begin{array}{l}. \\
\therefore \\
\therefore \\
\text { tions } \\
\text { orm } \\
\text { rious } \\
\ldots\end{array}$ & $\begin{array}{r}14 \\
9 \\
9 \\
8 \\
6\end{array}$ & $\begin{array}{l}\text { Dysarthria } \\
\text { Blurring of v } \\
\text { Nausea or vo } \\
\text { Insomnia .. } \\
\text { Dyspnoea .. } \\
\text { Paraesthesiae } \\
\text { Papular rash } \\
\text { Ptosis ... }\end{array}$ & $\begin{array}{l}\cdots \\
\text { ing } \\
\cdots \\
\cdots \\
\cdots \\
\cdots\end{array}$ & $\begin{array}{l}5 \\
4 \\
3 \\
3 \\
2 \\
2 \\
1 \\
1\end{array}$ \\
\hline
\end{tabular}

Unlike the psychotic episodes seen by Liske and Forster (1963), those occurring in this series did so against a normal background in all but one patient who had had a vaguely paranoid approach to life for some years. Of the side-effects which appeared, nine did so within 24 hours, seven in two days, seven within a week, two in two weeks, one in three weeks, and two in one month.

\section{Conclusions}

Very different results have been obtained by various workers from the administration of sulthiame, and in an awareness of frequent and serious side-effects our results are much more in keeping with the findings of LaVeck et al. (1962) and Liske and Forster (1963) in America than with those of the original German workers. There seems no doubt that sulthiame can exert a powerful anticonvulsant action, but its usefulness is limited by widespread and often alarming and serious side-effects. On this basis we feel that it is safer to admit patients to hospital for stabilization with the drug, although as the bulk of the side-effects appear within a week this need not be for a long period.

\section{Summary}

Sulthiame has been used in the treatment of 54 severe cases of epilepsy not controlled by other drugs. It had a valuable anticonvulsant action in 20 of these patients.

Severe side-effects were seen in 28 of the patients taking the drug.

In spite of these side-effects sulthiame is of value in the most-resistant epileptics.

Because of its side-effects, under no circumstances should sulthiame be used as the first drug in the treatment of any form of epilepsy.

We wish to thank Messrs. F.B.A. Pharmaceuticals, Limited, who supplied the sulthiame ("ospolot") which was used in this trial.

\section{REFERENCES}

Bray, C. A. R., and Bower, B. D. (1963). Develop. Med. Child Neurol.,

Davies, T. S., and Leyshon, M. W. (1963). Lancet, 2, 939.

Engelmeier, M. P. (1960). Dtsch. med. W schr., 85, 2207.

Fluegel, F., Bente, D., and Itil, T. (1960). Ibid., 85, 2199.

Haran, T. (1962). Irish 7. med. Sci., pp. 441, 427 .

Ingram, T. T. S., and Ratcliffe, S. G. (1963). Develop. Med. Child Neurol., 5, 313.

LaVeck, G. D., de la Cruz, F., and Thomas, D. B. (1962). Neurology (Minneap.), 12, 923.

Liske, E., and Forster, F. M. (1963). 7. New Drugs, 3, 32.

Overvad, E. (1962). Ugeskr. Lag., 124, 1400.

Raffauf, H. J. (1960). Dtsch. med. W wchr., 85, 2203. Wirth, W., Hoffmeister, F., Friebel, H., and Sommer, S. (1960). Ibid.,
85, 2195 .
In three years before the use of external massage six cases of circulatory arrest were treated and the same number of cases were seen in the subsequent six months. The larger number of cases seen latterly is due to my interest in the problem and not to an increase in incidence of the condition. Acid-base measurements were obtained in five of the last six cases, and four were treated with sodium bicarbonate solution. The clinical features in all 12 cases are given (Table I) and briefly summarized (Table II). The arrest occurred in the operating-theatre in eight cases; effective cardiac function was restored in seven cases, and in three of these the patients survived.

Acid-base Data.-Attention was directed to the importance of acidosis by Case 7, which has been previously reported (Stewart, Stewart, and Gillies, 1962). The acid-base data for four subsequent cases of circulatory arrest are shown (Table III). The absence of acidosis in one patient (Case 9) illustrates that it does not inevitably result from cardiac arrest. In this patient the arrest was noticed and was treated immediately, and * Lecturer in Surgery, University of St. Andrews, Queen's College,
Dundee. Present address: The Radcliffe Infirmary, Oxford. 
TABLE I.-Circulatory Arrest : Clinical Data

\begin{tabular}{|c|c|c|c|c|c|c|c|}
\hline $\begin{array}{l}\text { Case } \\
\text { No. }\end{array}$ & Age & Diagnosis & $\begin{array}{l}\text { Place and Time of } \\
\text { Arrest }\end{array}$ & $\begin{array}{l}\text { Type of } \\
\text { Massage* }\end{array}$ & $\begin{array}{l}\text { Condition of } \\
\text { Heart }\end{array}$ & Result & Notes \\
\hline 1 & 9 & $\begin{array}{l}\text { Posterior cranial fossa } \\
\text { tumour }\end{array}$ & $\begin{array}{l}\text { In theatre during } \\
\text { operation }\end{array}$ & I.C.M. & Asystole & $\begin{array}{l}\text { Cardiac function } \\
\text { restored }\end{array}$ & $\begin{array}{l}\text { Haemothorax from internal } \\
\text { mammary vein }\end{array}$ \\
\hline 2 & 7 & $\begin{array}{l}\text { Pleural effusion after } \\
\text { thoracotomy }\end{array}$ & $\begin{array}{l}\text { In anaesthetic-room } \\
\text { during induction }\end{array}$ & ” & " & $\begin{array}{l}\text { Resuscitation and } \\
\text { survival }\end{array}$ & 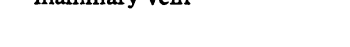 \\
\hline 3 & 1 & $\begin{array}{l}\text { Acute appendicitis; } \\
\text { peritonitis }\end{array}$ & $\begin{array}{l}\text { In ward, } 12 \text { hours after } \\
\text { operation }\end{array}$ & " & 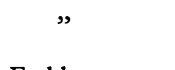 & No resuscitation & $\begin{array}{l}\text { Feeble spontaneous heart- } \\
\text { beats after massage, later } \\
\text { heart-block and asystole }\end{array}$ \\
\hline 4 & 23 & Multiple injuries & $\begin{array}{l}\text { In theatre before } \\
\text { craniotomy }\end{array}$ & " & $\begin{array}{l}\text { Feebly } \\
\text { contracting }\end{array}$ & & \\
\hline 5 & 68 & Intestinal obstruction & $\begin{array}{l}\text { In theatre before } \\
\text { extubation }\end{array}$ & None & & ” & $\begin{array}{l}\text { No response to intracardiac } \\
\text { adrenaline: I.C.M. not } \\
\text { attempted }\end{array}$ \\
\hline 6 & 69 & Bleeding duodenal ulcer & $\begin{array}{l}\text { In theatre during } \\
\text { operation }\end{array}$ & I.C.M. & Asystole & " & Heart rupture during massage \\
\hline 7 & & $\begin{array}{l}\text { Post-operative salt- } \\
\text { losing nephritis }\end{array}$ & $\begin{array}{l}\text { In ward, } 12 \text { days after } \\
\text { operation }\end{array}$ & $\begin{array}{l}\text { E.C.M. } \\
\text { I.C.M. }\end{array}$ & & $\begin{array}{l}\text { Resuscitation and } \\
\text { survival }\end{array}$ & \\
\hline 8 & & Fracture neck of femur & $\begin{array}{l}\text { In theatre during } \\
\text { operation }\end{array}$ & $\begin{array}{l}\text { E.C.M. } \\
\text { I.C.M. }\end{array}$ & $\begin{array}{l}\text { Ventricular } \\
\text { fibrillation }\end{array}$ & No resuscitation & $\begin{array}{l}\text { Heart rupture during massage : } \\
\text { pulmonary oedema }\end{array}$ \\
\hline 9 & 5 & Ventricular septal defect & " & I.C.M. & Asystole & $\begin{array}{l}\text { Cardiac function } \\
\text { restored }\end{array}$ & $\begin{array}{l}\text { Acid-base monitoring during } \\
\text { operation }\end{array}$ \\
\hline 11 & $\begin{array}{r}10 \\
2\end{array}$ & $\begin{array}{l}\text { Extradural haematoma } \\
\text { Extensive burns }\end{array}$ & $\begin{array}{l}\text { In hospital corridor just } \\
\text { after admission } \\
\text { In anaesthetic-room }\end{array}$ & $\begin{array}{c}\text { E.C.M. } \\
\text {, }\end{array}$ & $\begin{array}{l}\text { Feebly } \\
\text { contracting }\end{array}$ & $\begin{array}{l}\text { Cardiac function } \\
\text { restored } \\
\text { Resuscitation and }\end{array}$ & $\begin{array}{l}\text { E.C.G. showed heart-block } \\
\text { before bicarbonate therapy }\end{array}$ \\
\hline 12 & 9 days & $\begin{array}{l}\text { Patent ductus and ventric- } \\
\text { ular septal defect }\end{array}$ & $\begin{array}{l}\text { In ward, one day after } \\
\text { operation }\end{array}$ & $\begin{array}{l}\text { E.C.M. } \\
\text { I.C.M. }\end{array}$ & Asystole & $\begin{array}{l}\text { Cardiac function } \\
\text { restored }\end{array}$ & $\begin{array}{l}\text { Weak pulses became stronger } \\
\text { after bicarbonate therapy }\end{array}$ \\
\hline
\end{tabular}

* Internal (I.C.M.) or external (E.C.M.) cardiac massage.

the absence of acidosis is doubtless related to the avoidance of anoxia. Acidosis may thus be prevented by prompt treatment. In two patients very severe metabolic acidosis was completely corrected by intravenous infusion of sodium bicarbonate solution. In one of these patients (Case 10) peripheral pulses were not detectable prior to the administration of bicarbonate, but immediately after giving this they became strong. In the other patient (Case 12) weak pulses became stronger after bicarbonate was given. In both cases restoration of cardiac function was satisfactory, although the patients died subsequently. In one patient (Case 8) with severe respiratory acidosis due to pulmonary oedema following myocardial infarction attempts at resuscitation were abandoned before correction of the acidosis.

Unsatisfactory Management.-Management of the arrest was unsatisfactory in five cases. In two patients the heart was ruptured (Cases 6 and 8) during internal massage. Bleeding occurred in one other patient (Case 1): haemothorax was subsequently dealt with, but it probably contributed to the patient's death a few hours later. Massage was not attempted in Case 5 although a similar case would now be treated by external cardiac massage. In one of the earliest patients (Case 3) it seems highly probable that uncorrected acidosis prevented restoration of cardiac function. Heart-block and asystole, which occurred in this patient, have subsequently been shown (Stewart, Stewart, Morgan, and McGowan, 1964) to be common in very severe acidosis produced experimentally in animals.

TABLE II.-Summary of Cases

\begin{tabular}{|c|c|c|c|c|c|c|c|c|c|c|c|c|}
\hline \multirow[b]{2}{*}{ Case No. } & \multicolumn{6}{|c|}{$\begin{array}{c}\text { 1959-61 } \\
\text { (Three Years) }\end{array}$} & \multicolumn{6}{|c|}{$\begin{array}{c}1962 \\
\text { (Six Months) }\end{array}$} \\
\hline & 1 & 2 & 3 & 4 & 5 & 6 & 7 & 8 & 9 & 10 & 11 & 12 \\
\hline 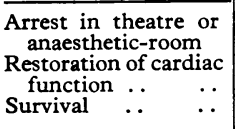 & $\begin{array}{l}+ \\
+\end{array}$ & $\begin{array}{l}+ \\
+ \\
+\end{array}$ & & + & + & + & $\stackrel{+}{+}$ & + & $\begin{array}{l}+ \\
+\end{array}$ & + & $\begin{array}{l}+ \\
+ \\
+\end{array}$ & + \\
\hline
\end{tabular}

TABLE III.-Acid-base Data

\begin{tabular}{|c|c|c|c|c|c|c|}
\hline $\begin{array}{l}\text { Case } \\
\text { No. }\end{array}$ & $\begin{array}{c}\text { Time after } \\
\text { Cardiac } \\
\text { Arrest } \\
\text { (Minutes) }\end{array}$ & $\begin{array}{l}\text { Blood } \\
\text { Sample }\end{array}$ & $p \mathrm{H}$ & $\underset{(\mathrm{mm} \cdot \mathrm{Hg})}{\mathrm{PcO}_{2}}$ & $\begin{array}{c}\text { Total } \\
\text { Bicarbonate } \\
\text { given } \\
\text { (mEq) }\end{array}$ & $\begin{array}{c}\text { Predominant } \\
\text { Type } \\
\text { of } \\
\text { Acidosis }\end{array}$ \\
\hline 8 & $\begin{array}{l}30 \\
60\end{array}$ & $\begin{array}{c}\text { Arterial } \\
,\end{array}$ & $\begin{array}{l}6 \cdot 69 \\
7.00\end{array}$ & $\begin{array}{r}112 \\
78\end{array}$ & $\begin{array}{r}0 \\
150\end{array}$ & Respiratory \\
\hline & $\begin{array}{r}-10 \\
30\end{array}$ & ", & $\begin{array}{l}7 \cdot 38 \\
7 \cdot 35\end{array}$ & $\begin{array}{l}44 \\
42\end{array}$ & $\begin{array}{l}0 \\
0\end{array}$ & None \\
\hline 10\{ & $\begin{array}{r}70 \\
190\end{array}$ & $\begin{array}{c}\text { Venous } \\
\text {, }\end{array}$ & $\begin{array}{l}6 \cdot 76 \\
7 \cdot 34\end{array}$ & $\begin{array}{l}84 \\
49\end{array}$ & $\begin{array}{r}0 \\
225\end{array}$ & Metabolic \\
\hline & $\begin{array}{r}30 \\
195\end{array}$ & "’ & $\begin{array}{l}6 \cdot 61 \\
7 \cdot 34\end{array}$ & $\begin{array}{l}48 \\
51\end{array}$ & $\begin{array}{r}6 \\
66\end{array}$ & " \\
\hline
\end{tabular}

\section{Discussion}

The data (Table II) indicate that resuscitation is being attempted more frequently in less than optimal circumstances, but in spite of this it is being rewarded more often by success, at least in respect of cardiac function. External cardiac massage, which achieves a satisfactory artificial circulation without special apparatus, permits the earliest possible treatment of cardiac arrest. The data in this paper support the view that restoration of effective cardiac function depends in some cases on the subsequent correction of acidosis.

Nomenclature.-Acid-base nomenclature is somewhat illogical, for cause and effect are not always clearly distinguished. Although carbon dioxide is produced by cell metabolism (and could properly be described as metabolic in origin) the acidosis which results from its accumulation in the blood is described as " respiratory acidosis" because it is usually related to failure of the respiratory mechanism for gaseous exchange. In practice, therefore, hypercapnia is usually associated with anoxia. They result from a common cause. The term "metabolic acidosis" is used when there is accumulation in the blood of acids other than carbonic acid. It may be due to excessive acid production in consequence of increased metabolism or to decreased acid elimination with failure of the hepatic or renal mechanisms. Anoxia is a potent cause of metabolic acidosisfirstly, because acid metabolites are increased during anaerobic metabolism, and, secondly, because hepatic and renal damage may result.

\section{Occurrence of Acidosis}

The occurrence of acidosis after cardiac arrest has not received much attention although the aetiological importance of hypercapnia has been recognized for some time. The acidosis which follows cardiac arrest may be of metabolic or respiratory type. Metabolic acidosis after cardiac arrest has been noted by several authors. Jude, Kouwenhoven, and Knickerbocker (1961) comment that "metabolic acidosis if present should be corrected," and Martin (1961) states that "sodium bicarbonate solution in a dose of $44.5 \mathrm{mEq}$ should be given intravenously in an adult if cardiac collapse persists beyond five minutes. It may be repeated every ten minutes for six doses. Its main effect is to reverse metabolic acidosis readily detected by proper laboratory procedures." Brooks and Feldman (1962a), who noted metabolic acidosis in two cases of cardiac arrest, suggest that sodium bicarbonate should be given in every case of cardiac arrest, and Stewart et al. (1962), who reported in detail the present Case 7, suggested that the correction of acidosis was an important factor in resuscitation. 
Metabolic Acidosis.-Very few acid-base data have been published about patients who have had a cardiac arrest. Brooks and Feldman (1962a) reported an arterial blood $p \mathrm{H}$ level of 6.92 in one of their two cases, and in the present Case 7 (Stewart et al., 1962) the $p \mathrm{H}$ of venous blood was 7.06. In the present series data from two cases (Nos. 10 and 12) illustrate the very severe acidosis which may be found after cardiac arrest: venous $p \mathrm{H}$ levels of 6.76 and 6.61. In the former case the acidosis was of the mixed type (venous $\mathrm{PCO}_{2} 84 \mathrm{~mm}$. $\mathrm{Hg}$ ), and in the latter case the acidosis appeared to be entirely metabolic (venous $\mathrm{PcO}_{2}$ $48 \mathrm{~mm}$. $\mathrm{Hg}$ ). In both cases acid-base equilibrium was rapidly restored by administration of sodium bicarbonate solution and was associated with an immediate improvement of cardiac function.

Respiratory Acidosis.-Hypercapnia with consequent respiratory acidosis may follow cardiac arrest. It is commonly caused by inhalation of vomitus and by left ventricular failure. Both of these conditions may be complicated by pulmonary oedema. In the present series moderately severe respiratory acidosis (venous $\mathrm{PCO}_{2} 84 \mathrm{~mm}$. $\mathrm{Hg}$ ) in Case 10 was probably related to inhalation of vomitus, and very severe respiratory acidosis (venous $\mathrm{PCO}_{2} 112 \mathrm{~mm}$. $\mathrm{Hg}$ ) in Case 8 was caused by coronary thrombosis with acute left heart failure and pulmonary oedema. In the former case the $\mathrm{PCO}_{2}$ was normal after tracheal toilet, and in the latter case attempts at resuscitation were abandoned.

Anoxia.-In clinical practice it is rarely possible to measure the extent of tissue anoxia which occurs in cases of cardiac arrest. There is, of course, less anoxia when the period of circulatory arrest is short, but in practice this period too is difficult to estimate. In Case 9, however, the duration of circulatory arrest was certainly less than 30 seconds and probably less than 10. The absence of metabolic acidosis is doubtless related to the avoidance of anoxia.

\section{Management of Cardiac Arrest}

It has often been emphasized that the establishment of an airway and inflation of the lungs, to relieve anoxia and hypercapnia, is as important in resuscitation as restoration of the circulation. It is the principal purpose of this paper to emphasize that treatment of acidosis is the next priority in the management of cardiac arrest. Correction of acidosis may be essential for restoration of heart-beat, though other measures, such as the administration of adrenaline and of calcium salts, may be valuable. Finally, of course, it is important to treat the cause of the arrest.

\section{Bicarbonate Therapy}

Bicarbonate therapy corrected the very severe metabolic acidosis which followed cardiac arrest in Cases 10 and 12, but the absence of acidosis in Case 9 emphasized that metabolic acidosis results primarily from anoxia and therefore not inevitably from circulatory arrest. Thus the recommendation of Brooks and Feldman (1962a), that sodium bicarbonate should be given in every case of cardiac arrest, cannot be accepted without reserve, and these authors have subsequently noted (Brooks and Feldman, 1962b) that bicarbonate is not always necessary for resuscitation. It is nevertheless important that sodium bicarbonate should be given empirically if it seems likely that serious anoxia has resulted. The scheme advocated by Martin (1961) is useful, particularly so if laboratory facilities are not available. In the present series, however, the practice has been to give a larger adult dose $(150 \mathrm{mEq})$ of sodium bicarbonate if indicated-that is, if circulatory arrest was thought in retrospect to have been present for two minutes or more and to obtain a blood sample for acid-base measurements. From these measurements the amount of bicarbonate necessary to restore normal acid-base balance may be readily calculated.
As a result of the experience gained from the present cases it is recommended that sodium bicarbonate solution $(8.4 \%$, or $1 \mathrm{mEq} / \mathrm{ml}$.) be made available for the treatment of cases of cardiac arrest. If the period of circulatory arrest is thought to have been very short (less than 30 seconds) bicarbonate therapy is unlikely to be necessary, but if there is any doubt $50 \mathrm{mEq}$ may be given to an adult. In an adult subject with normal acid-base equilibrium this dose will cause only slight alkalosis. If the period of circulatory arrest is thought to have been long -two to three minutes or more-or if external cardiac massage has been carried out for 20 minutes or more, an initial adult dose of $150-200 \mathrm{mEq}$ is recommended. The need for further therapy is indicated by acid-base measurements.

\section{General Management}

The data show that other aspects of management require attention. In the present small series severe haemorrhage occurred three times, with heart rupture twice, although the risk of this has long been recognized (McMillan, 1955), and there were five cases in which for a variety of reasons cardiac function was not restored.

From experience I have found an effective method of internal massage, used when the pericardium is open, which may be carried out without fatigue by one operator for more than an hour. One hand is used and the heart is compressed between the flat palmar surfaces of the operator's fingers and the posterior surface of the patient's sternum. Compression is assisted by the thumb, outside the chest, pressing on the skin over the anterior surface of the sternum. Massage may be carried out with either hand: from the patient's left side by the operator's left hand, his forearm being supinated, and from the patient's right 'side by the operator's right hand with his forearm pronated. I have often used this method of massage, both in patients and in experimental animals, and it has not so far been my misfortune to cause heart rupture with this or any other method. The method is not entirely satisfactory if the heart is large, and some precautions are necessary. One must be quite sure that there is no rib fracture or irregularity of the chest wall which might cause rupture of the heart, and compression must be carried out without pulling on the pulmonary veins and other structures at the base of the heart.

A pragmatic approach to the management of cardiac arrest is desirable. Team-work is essential, and it is the responsibility of the members of the operating team to be familiar with the emergency procedure should cardiac arrest occur. Finally, it should be remembered that many if not most remediable cases. of cardiac arrest are preventable.

\section{Summary}

The management of six earlier cases of circulatory arrest are compared with six cases treated after the introduction of external cardiac massage and of acid-base measurements. In the latter cases cardiac function was restored more often, although resuscitation was attempted in less than optimal circumstances. Acid-base measurements were obtained in four of the latter cases. Severe metabolic acidosis, present in two cases, was completely, corrected by administration of intravenous sodium bicarbonate solution. Severe respiratory acidosis was present in one case. In the fourth case, in which the period of circulatory arrest was very short, there was no acidosis. External cardiac massage permits the earliest possible treatment of cardiac arrest. Metabolic acidosis is often the result of cardiac arrest irrespective of cause, and may be so severe that it prevents restoration of the heart-beat. It may be corrected by the intravenous administration of sodium bicarbonate solution.

It is a pleasure to acknowledge my indebtedness to Professor D. M. Douglas for advice and criticism, to Dr. H. G. Morgan for 
the biochemical results, and to several surgeons and anaesthetists for permission to report cases under their care.

\section{REFERENCES}

Brooks, D. K., and Feldman, S. A. (1962a). Anaesthesia, 17, 161. Brooks, D. (1962b). Lancet, $2,1111$.

Jude, J. R., Kouwenhoven, W. B., and Knickerbocker, G. G. (1961). 7. Amer. med. Ass., 178, 1063.
Kouwenhoven, W. B., Jude, J. R., and Knickerbocker, G. G. (1960) Ibid., 173, 1064 .

Lancet, 1962, 2, 976

McMillan, I. K. R. (1955). Brit. med. Bull., 11, 229.

Martin, S. J. (1961). Anesthesiology, 22, 738.

Stewart, J. S. S., Stewart, W. K., and Gillies, H. G. (1962). Lancet, 2 964. press. Morgan, H. G., and McGowan, S. (1964). Brit. Heart 7. In

\title{
Milk-borne Outbreak of Salmonella Heidelberg
}

\author{
R. IRENE HUTCHINSON,* M.D., D.P.H., D.T.M.
}

Brit. med. F., 1964, 1, 479-480

On 24 June 1963 a patient aged 21, living in Southampton, was admitted in labour to the General Hospital Maternity Unit. Soon after admission she passed a " rather loose" stool which was found to contain Salmonella heidelberg. On the same day faeces were received from a child aged $1 \frac{1}{2}$ years who lived in a New Forest village and had diarrhoea. Salm. montevideo was isolated. The child's father was found to be excreting Salm. montevideo. He was symptomless but had had diarrhoea two weeks previously. Also on 24 June a local veterinary surgeon brought in a culture of organisms for identification. They were isolated from a cow which was one of a number with acute enteritis in a herd from which the milk was being sold to the public as tuberculin-tested raw milk. The milk was being put into a number of vending machines in both the new Forest and the Southampton districts. The culture was found to be Salm. heidelberg.

A sample of milk taken from each of the vending machines showed that 11 contained Salm. heidelberg-three in the New Forest and eight in Southampton.

\section{Investigation}

Inquiries made of the mother from the maternity unit revealed that she did occasionally have a "milk drink" from a machine "near her shopping centre." This was one from which a positive milk had been found.

Faeces from workers and their families at the farm were examined (eight males and three females). Five of the 11 were excreting Salm. heidelberg, and among the latter were the head cowman, the poultryman, and the assistant vending-machine operator. On 3 July faeces from 10 cows with enteritis were received and all contained Salm. heidelberg. On 5 July a sample of feeding material as given to the cows was examined. It consisted of barley and appeared to be contaminated with rat faeces, and Salm. heidelberg was isolated.

On 24 July, and after veterinary treatment had been given to the affected cows, faeces from all the herd were examined. Sixtysix were free of salmonellae, but 11 yielded Salm. heidelberg and two specimens yielded Salm. montevideo.

On finding this second type of salmonella inquiries were made of the family from whom Salm. montevideo had been isolated on 24 June. The father stated that he had bought a milk drink from one of the vending machines but only he had consumed any. His diarrhoea had started about four days

* Director, Public Health Laboratory, Southampton ; Consultant Bacteriologist, Southampton Group Hospitals. later. The child had never had any but heat-treated milk. As the father was still excreting the organism at the time of the child's illness it would seem that the latter must have been infected from the father. Further inquiries about the cows showed that in 1961 there had been a small outbreak of enteritis among some calves and that the causal organism was then Salm. montevideo.

Although the sale of the raw milk had been immediately stopped, specimens from a number of cases of enteritis from which Salm. heidelberg was isolated occurred during the next week or two.

The accompanying Table shows the age and sex distribution of excreters and mode of infection. Four children (aged 6 months, 8 years, 8 years, and 15 years) were ill enough to be

Sex and Age Distribution and Mode of Infection of Salm. Heidelberg Excreters (Exclusive of Persons and Their Families at the Affected Farm)

\begin{tabular}{|c|c|c|c|c|c|c|c|}
\hline Years : & $<1$ & 1 & 2 & 5 & $14-21$ & $>21$ & Total \\
\hline $\begin{array}{ccc}\text { Isolation of salmonellae } & \ldots \\
\text { No. of males } & . . & \ldots \\
\text { No of females } & \ldots & \ldots\end{array}$ & $\begin{array}{l}3 \\
1 \\
2\end{array}$ & $\begin{array}{l}1 \\
1 \\
0\end{array}$ & $\begin{array}{l}7 \\
4 \\
3\end{array}$ & $\begin{array}{c}12 \\
7 \\
5\end{array}$ & $\begin{array}{l}2 \\
2 \\
0\end{array}$ & $\begin{array}{l}3 \\
2 \\
1\end{array}$ & $\begin{array}{l}28 \\
17 \\
11\end{array}$ \\
\hline $\begin{array}{l}\text { No. having drunk milk from } \\
\text { vending machines ... } \\
\text { No. infected from family con- }\end{array}$ & 1 & 0 & 3 & 11 & 2 & 3 & 20 \\
\hline $\begin{array}{l}\text { tact with an excreter } \\
\text { No. excreting salmonellae with } \\
\text { no obvious mode of infection }\end{array}$ & 2 & 0 & 2 & 0 & - & - & 4 \\
\hline
\end{tabular}

Salm. montevideo excreters 2 -father and son (aged 15 months).

Origin of infection: Father drank milk from vending machine-developed diarrhoea. Son had no milk from vending machine-developed diarrhoea about two weeks later.

Source of infection: Probably contact with father. (Father was a symptomless excreter.)

admitted to hospital. Symptoms included pyrexia, abdominal pain, diarrhoea, and vomiting, all of varying degrees of severity. The incubation period averaged four days in most of the patients.

It will be seen that from all sources (farm 5, district 28) there were 33 human excreters of Salm. heidelberg and two of Salm. montevideo. Excluding the workers at the farm, who could be considered to be in close contact with the affected herd, there were 28 excreters of Salm. heidelberg, and 20 of these had drunk milk from one or other of the vending machines a few days before the onset of their illness. Four excreters had never had any of the milk, but there was at least one other excreter of the organism in the house, so that a family cross-infection was probable. It was impossible to decide the source of infection of four persons as no one else in the family was infected and no history of having drunk any milk from the machines was obtained. 